http://jmscr.igmpublication.org/home/

ISSN (e)-2347-176x ISSN (p) 2455-0450

crossref DOI: https://dx.doi.org/10.18535/jmscr/v8i12.30

Journal Of Medical Science And Clinical Research

IGM Publication

An Official Publication of IGM Publication

\title{
Multidrug Resistant Gram Negative Bacterial Isolates from Intensive Care Unit in a Tertiary Care Centre in Kerala with Special Reference to Molecular Detection of BLA NDM1 Gene
}

\author{
Authors \\ Dr Chris Mary Antony ${ }^{1}$, Dr Jilse George ${ }^{2}$, Dr Sivaraman ${ }^{3}$, Dr Gayathri K B \\ ${ }^{1}$ Junior Resident, Microbiology, Govt Medical College, Ernakulam \\ ${ }^{2}$ Professor of Medicine, Govt Medical College, Ernakulam \\ ${ }^{3}$ Principal Scientist, Central Institute of Fisheries Technology, Kochi \\ ${ }^{4}$ Senior Resident, Microbiology, Govt Medical College, Ernakulam \\ *Corresponding Author \\ Dr Lancy Justus \\ Professor of Microbiology, Govt. Medical College, Ernakulam, Kerala, India
}

\begin{abstract}
The emergence of antibiotic resistance among microorganisms has become a global problem. One of the mechanisms by which bacteria acquire resistance to antimicrobial agents is by the production of enzymes that either destroy or modify the antibiotic before it reaches the target. One among them is metallo beta lactamases (MBL). The importance of NDM-1 gene is that it inactivates all beta lactams except aztreonam. Treatment of multidrug resistant bacteria causes a serious challenge to physicians treating patients in ICUs. A study was conducted in the Dept. of Microbiology, Govt. Medical College, Ernakulam for a period of one year from July 2018 to June 2019. A total number of 200 isolates obtained from clinical samples of patients admitted in different ICUs were included in the study. Out of the 200 isolates, 164 were Gram negative bacteria. Among them 104(52\%) were multidrug resistant. The predominant MDR Gram negative isolate was Acinetobacter species (32\%) followed by Klebsiella species (29\%) and E.coli (26\%). Majority of the isolates were obtained from sputum samples (42\%). Proportion of metallo beta lactamase production was detected by phenotypic methods such as double disk synergy test and modified Hodge test. Molecular characterization, especially detection of NDM-1 gene was done by RT PCR. NDM-1 gene was detected in $8.5 \%$ of the isolates predominantly in Acinetobacter species (58.82\%) followed by E.coli (23.5\%) and Klebsiella species (17.64\%). Among patients who had infection with MDR Gram negative bacteria, 54.8\% of the patients improved after appropriate antibiotic therapy. Mortality rate in our study was $41 \%$ which is lower than the mortality rate reported by previous studies in India.

Keywords: Gram negative bacteria, multidrug resistant, metallobetalactamase.
\end{abstract}

\section{Introduction}

Infections in patients admitted in ICUs are commonly caused by multi-drug resistant microorganisms. Antibiotic resistance is rising in developing countries throughout the world including India. Multi drug resistance is defined as acquired non susceptibility to atleast one agent in three or more antimicrobial categories. Among the MDR micro-organisms producing infections in ICU, Gram negative bacilli like Pseudomonas, E.coli, Klebsiella and Acinetobacter species are the commonly isolated organisms from clinical 
samples such as sputum, urine, exudates, sterile fluids and blood.

\section{Objectives}

1. To find out the proportion of multidrug resistant Gram negative isolates among bacterial isolates from the clinical samples collected from patients admitted in ICUs at Govt Medical College, Ernakulam from July 2018 to June 2019.

2. To detect the metallobetalactamase producers among MDR Gram negative isolates by phenotypic methods

3. To find out the proportion of blaNDM-1 gene harbouring MBL producers by genotypic method using RT PCR.

\section{Methodology}

Study Design: Descriptive, cross sectional study

Study Setting: Dept. of Microbiology, MICU, CICU, SICU of Govt. Medical College, Ernakulam

Study Period: One year (from 1st July 2018 to $30^{\text {th }}$ June 2019)

Study Population: All patients admitted in ICUs during study period

Inclusion Criteria: All isolates obtained from all specimens of patients admitted in ICUs.

Exclusion Criteria: Isolates from pediatric and neonatal ICUs

Sample Size: 200

Calculated using formula

$$
\mathrm{n}=(\mathrm{Za})^{2} \times \mathrm{p} \times \mathrm{q} / \mathrm{d}^{2}
$$

$\mathrm{Z}=1.96$ at $5 \%$ level of significance

$\mathrm{p}=$ prevalence taken from previous similar study which is $36 \%$

$\mathrm{q}=100-\mathrm{p}$

$\mathrm{d}=20 \%$ of $\mathrm{p}=7$

Sampling Technique: non probability sampling Study Variables:

Age group of the patient,

Gender of the patient,

Location of the patient in the hospital,

Sample type,
Previous hospitalization

Prior ICU admission

Use of antibiotics in treatment

Co-morbidities

Study Procedure: Samples collected from patients admitted in ICUs during the study period were received in the Bacteriology laboratory, in the Dept of Microbiology at GMC, Ernakulam for processing. Samples such as sputum, exudates, sterile fluids were subjected to Gram staining after preparing smear from the samples immediately after receiving the samples. Urine samples were subjected to wet mount preparation to find out the presence of pus cells and motile bacteria. Blood samples were inoculated into Brain Heart Infusion broth and kept in the incubator at $37^{\circ} \mathrm{C}$ overnight. After the preliminary staining and wet mount preparations, samples were inoculated onto Blood agar, Chocolate agar and MacConkey agar. Next day, the plates are observed for bacterial growth. Bacteria identified by colony morphology, Gram staining, motility testing by Hanging drop preparation, Oxidase test, catalase test and other relevant biochemical reactions. After identification of the organism obtained by culture, antibiotic sensitivity was performed by KirbyBauer disc diffusion method on Mueller - Hinton agar plate. The diameter of the zone of inhibiton around each antibiotic measured and interpreted according to clinical Laboratory Standard Institute (CLSI) guidelines. Gram Negative isolates showing resistance to atleast one agent in any of the three groups of antimicrobials were considered as multidrug resistant and stocked in test tubes containing semisolid nutrient agar slopes for further characterization.

\section{Phenotypic Screening Tests Modified Hodge test (MHT)}

For detection of carbapenemase, this test was performed according to CLSI guidelines. 0.5 McFarland turbidity suspension of negative control of E.coli ATCC 25922 was uniformly swabbed onto Mueller Hinton agar plate and the 
test isolate was streaked as a straight line from the edge of the Meropenem disc to the edge of the plate. An indentation in the growth of the negative control towards the Meropenem disc on either side of the test isolate was considered as positive for the production of carbapenemases by the test isolate.

\section{Double disk synergy test (DDST)}

This test was performed using 2 Imipenem (10 $\mu \mathrm{g})$ discs (IPM) one containing $10 \mu \mathrm{l}$ of $0.1 \mathrm{M}$ $(292 \mu \mathrm{g})$ anhydrous EDTA and other one without EDTA. These discs were placed $25 \mathrm{~mm}$ apart. An increase in zone diameter of $>4 \mathrm{~mm}$ around IPMEDTA disc compared to that of the IPM alone disc was considered positive for MBL production. These isolates were considered to be of the MBL positive phenotype.

\section{Genotypic Assay for Detection of NDM-1 Gene}

This was done at Central Institute of Fisheries Technology, Willington Island, Ernakulam. DNA from bacterial isolates was extracted from the culture sample by alkaline lysis method. Presence of bla NDM-1 gene was established by real time PCR with specific primers targeting the gene.

\section{Results}

A total number of 200 bacteral isolates obtained by culture of the clinical specimens collected from patients admitted in different ICUs (MICU, SICU, CICU) during a period of one year from July 2018 to June 2019 were included in the study.

Majority of isolates were obtained in the age group between 61-70 yrs. The youngest patient was 14 years old. The upper age limit was 89 years. Male preponderance was observed in this study. $56 \%$ were males and $44 \%$ were females in the study population. The male- female ratio was $1.2: 1$

Out of the 200 isolates, majority was obtained from sputum samples (36.5\%) followed by urine (26.5\%), exudates $(20.5 \%)$ and blood (15\%). Only $0.5 \%$ isolates were obtained from stool samples. Most of the isolates were Gram negative bacteria, $164(82 \%)$ and only $18 \%$ were gram positive bacteria. Predominantly gram negative bacterial isolates were obtained from sputum samples $(44.5 \%)$. Majority of the isolates were obtained from patients admitted in MICU (61\%)

Table 1: Age Wise Distribution of the Study Population

\begin{tabular}{|l|c|c|}
\hline Age (in years) & Number & Percentage \\
\hline $12-20$ & 8 & $4 \%$ \\
\hline $21-30$ & 10 & $5 \%$ \\
\hline $31-40$ & 6 & $3 \%$ \\
\hline $41-50$ & 20 & $10 \%$ \\
\hline $51-60$ & 41 & $20.5 \%$ \\
\hline $61-70$ & 54 & $27 \%$ \\
\hline $71-80$ & 43 & $21.5 \%$ \\
\hline $81-90$ & 18 & $9 \%$ \\
\hline Total & $\mathbf{2 0 0}$ & $\mathbf{1 0 0 \%}$ \\
\hline
\end{tabular}

Table 2: Gender Distribution of the Study Population

\begin{tabular}{|l|c|c|}
\hline Gender & Number & Percentage \\
\hline Male & 112 & $56 \%$ \\
\hline Female & 88 & $44 \%$ \\
\hline Total & $\mathbf{2 0 0}$ & $\mathbf{1 0 0 \%}$ \\
\hline
\end{tabular}

Table 3: Distribution of Isolates from Different Samples from ICUS

\begin{tabular}{|l|c|c|}
\hline Sample Type & Total & Percentage \\
\hline Sputum & 73 & $36.5 \%$ \\
\hline Urine & 53 & $26.5 \%$ \\
\hline Exudates & 41 & $20.5 \%$ \\
\hline Blood & 30 & $15 \%$ \\
\hline Sterile Fluids & 2 & $1 \%$ \\
\hline Stool & 1 & $0.5 \%$ \\
\hline Total & $\mathbf{2 0 0}$ & $\mathbf{1 0 0 \%}$ \\
\hline
\end{tabular}

Table 4: Distribution of Isolates from Different Locations

\begin{tabular}{|l|c|c|}
\hline Sample Type & Total & Percentage \\
\hline MICU & 122 & $61 \%$ \\
\hline CICU & 41 & $20.5 \%$ \\
\hline SICU & 37 & $18.5 \%$ \\
\hline Total & $\mathbf{2 0 0}$ & $\mathbf{1 0 0 \%}$ \\
\hline
\end{tabular}


Table 5: Distribution of Gram Negative Isolates Obtained in ICUS

\begin{tabular}{|l|l|c|c|}
\hline Sl.No & Isolate & Number & Percentage \\
\hline 1 & Klebsiella species & 41 & $25 \%$ \\
\hline 2 & E coli & 40 & $24.39 \%$ \\
\hline 3 & Acinetobacter & 39 & $23.78 \%$ \\
\hline 4 & Pseudomonas aeruginosa & 24 & $14.62 \%$ \\
\hline 5 & Enterobacter species & 9 & $5.48 \%$ \\
\hline 6 & Proteus species & 2 & $1.22 \%$ \\
\hline 7 & Morganellamorganii & 2 & $1.22 \%$ \\
\hline 8 & Stenotrophomonas maltophila & 2 & $1.22 \%$ \\
\hline 9 & Vibrio cholerae & 1 & $0.61 \%$ \\
\hline 10 & Citrobacter species & 1 & $0.61 \%$ \\
\hline 11. & Salmonella paratyphi A & 1 & $0.61 \%$ \\
\hline 12 & Haemophilus influenza & 1 & $0.61 \%$ \\
\hline 13 & Aeromonashydrophila & 1 & $0.61 \%$ \\
\hline \multicolumn{2}{|r|}{ Total } & $\mathbf{1 6 4}$ & $\mathbf{1 0 0 \%}$ \\
\hline
\end{tabular}

Table 6: Distribution of MDR Gram Negative Isolates Obtained in ICUS

\begin{tabular}{|c|c|c|c|c|}
\hline \multirow[t]{2}{*}{ Sl.No } & \multirow[t]{2}{*}{ Isolate } & \multirow[t]{2}{*}{$\begin{array}{c}\text { Total Number of } \\
\text { Isolates }\end{array}$} & \multicolumn{2}{|c|}{$\begin{array}{c}\text { MDR Gram Negative } \\
\text { Isolates }\end{array}$} \\
\hline & & & Number & Percentage \\
\hline 1. & Acinetobacter species & 39 & 33 & $84.61 \%$ \\
\hline 2. & Klebsiella species & 41 & 31 & $75.61 \%$ \\
\hline 3. & E coli & 40 & 28 & $70 \%$ \\
\hline 4. & Pseudomonas aeruginosa & 24 & 5 & $20.8 \%$ \\
\hline 5. & Enterobacter species & 9 & 3 & $33.34 \%$ \\
\hline 6. & Morganellamorganii & 2 & 2 & $100 \%$ \\
\hline 7. & Stenotrophomonas maltophilia & 2 & 1 & $50 \%$ \\
\hline 8. & Citrobacter species & 1 & 1 & $100 \%$ \\
\hline & Total & 164 & 104 & $63.4 \%$ \\
\hline
\end{tabular}

Table 7: Distribution of MDR-GNB in Different Samples

\begin{tabular}{|c|c|c|c|}
\hline \multirow[t]{2}{*}{ Sample Type } & \multicolumn{2}{|c|}{$\begin{array}{c}\text { MDR Gram Negative } \\
\text { Isolates }\end{array}$} & \multirow[t]{2}{*}{$\begin{array}{c}\text { Total Number } \\
\text { of Isolates }\end{array}$} \\
\hline & Number & Percentage & \\
\hline Sputum & 44 & $60.27 \%$ & 73 \\
\hline Urine & 35 & $77.78 \%$ & 45 \\
\hline Blood & 14 & $70 \%$ & 20 \\
\hline Exudates & 11 & $45.83 \%$ & 24 \\
\hline Sterile Fluids & 0 & $0 \%$ & 1 \\
\hline Stool & 0 & $\%$ & 1 \\
\hline Total & 104 & $63.41 \%$ & 164 \\
\hline
\end{tabular}

Table 8: Distribution of MDR-GNB from Different Locations

\begin{tabular}{|l|c|c|c|}
\hline Sample Type & \multicolumn{2}{|c|}{ MDR Gram Negative Isolates } & Total \\
\hline & Number & Percentage & \\
\hline MICU & 64 & $61.5 \%$ & $104(63.4 \%)$ \\
\hline CICU & 22 & $59.45 \%$ & $37(22.5 \%)$ \\
\hline SICU & 18 & $54.55 \%$ & $33(20.12 \%)$ \\
\hline Total & $\mathbf{1 0 4}$ & $\mathbf{6 3 . 4 \%}$ & $\mathbf{1 6 4}$ \\
\hline
\end{tabular}

Table 9: Phenotypic Methods of Screening for MBL Product

\begin{tabular}{|l|c|c|c|c|c|c|}
\hline SI.No & $\begin{array}{c}\text { Name of the } \\
\text { Test }\end{array}$ & $\begin{array}{c}\text { Total Number of } \\
\text { Isolates Tested }\end{array}$ & \multicolumn{2}{|c|}{ Positive } & \multicolumn{2}{c|}{ Negative } \\
\hline & & & Number & Percentage & Number & Percentage \\
\hline 1. & DDST & 63 & 27 & $42.857 \%$ & 36 & $57.14 \%$ \\
\hline 2. & MHT & 63 & 2 & $3.17 \%$ & 61 & $96.82 \%$ \\
\hline
\end{tabular}


Table 10: Distribution of MDR-GNB Isolates with NDM-1 Gene

\begin{tabular}{|l|l|c|c|c|}
\hline Sl.No & Isolate & $\begin{array}{c}\text { Total Number } \\
\text { of Isolates }\end{array}$ & \multicolumn{2}{c|}{ MDR Gram Negative Isolates } \\
\hline & & & Number & Percentage \\
\hline 1. & Acinetobacter species & 33 & 10 & $30.3 \%$ \\
\hline 2. & E coli & 28 & 4 & $14.28 \%$ \\
\hline 3. & Klebsiella species & 31 & 3 & $9.67 \%$ \\
\hline 4. & Pseudomonas aeruginosa & 5 & 0 & 0 \\
\hline 5. & Enterobacter species & 3 & 0 & 0 \\
\hline 6. & Morganellamorganii & 2 & 0 & 0 \\
\hline 7. & Stenotrophomonas maltophilia & 1 & 0 & 0 \\
\hline 8. & Citrobacter species & 1 & 0 & $\mathbf{1 6 . 3 4 \%}$ \\
\hline \multicolumn{2}{|c|}{ Total } & $\mathbf{1 0 4}$ & $\mathbf{1 7}$ & \\
\hline
\end{tabular}

Table 11: Outcome of Patients Infected with MDR-GNB after Treatment

\begin{tabular}{|l|c|c|}
\hline $\begin{array}{l}\text { Patient Status After } \\
\text { Treatment }\end{array}$ & $\begin{array}{c}\text { Patients With Mdr Gram } \\
\text { Negatives Isolates }\end{array}$ & Percentage \\
\hline Patients recovered & 57 & $54.8 \%$ \\
\hline Patients expired & 40 & $38.46 \%$ \\
\hline Referred to higher center & 7 & $6.73 \%$ \\
\hline Total & $\mathbf{1 0 4}$ & $\mathbf{1 0 0 \%}$ \\
\hline
\end{tabular}

The predominant Gram negative bacteria isolated was Klebsiella species (21\%). E.coli isolated were $20 \%$ and Acinetobacter species (19\%).Among 164 Gram negative isolates, 104 (52\%) were multi drug resistant organisms. Predominant species of multi drug resistant isolates are Acinetobacter species, 33(32\%), followed by Klebsiella species, 31(29\%) and E.coli, 28(27\%).

Majority of the patients with MDR isolates were from MICU. Previous hospitalization was noted in 59 patients $(56.73 \%)$ out of the 104 patients ibfected with MDR Gram negative bacteria. Chisquare test done to find out the significance. Association between previous hospitalization and MDR Gram negative bacteria was found to be statistically significant.

Prior admission in ICU was found in 36 patients (34.6\%) out of the 104 patients with MDR Gram negative bacterial infection. Association between prior ICU admission and MDR Gram negative isolates was found to be statistically significant based on the chi-square test with $p$ value of 0.001 $(<0.05)$

The common co-morbidities associated with MDR Gram negative isolates are Diabetes mellitus $(52.8 \%)$, hypertension $(38.46 \%)$, coronary artery disease (23.07\%), COPD (13.4\%), CVA (6.73\%).
But no significant association was found between these factors and occurance of MDR Gram negative isolates.

Among 104 MDR Gram negative isolates, $63(60.57 \%)$ were metallobetalactamase producers detected by phenotypic methods. PCR is the gold standard for detecting NDM-1 gene in the isolates. 17 isolates (26.98\%) were having NDM-1 gene detected by real time PCR.

Among 63 MBL producers detected, double disk synergy test (DDST) and Modified Hodge test (MHT) which are phenotypic tests are used as screening tests. Sensitivity of DDST was found to be $88.2 \%$ and specificity $73.91 \%$. Sensitivity of MHT was found to be $5.8 \%$ and specificity $97.8 \%$.

NDM was most commonly isolated from sputum samples $(52.94 \%)$ followed by urine samples $(35.29 \%)$ and blood (11.76\%). The common bacterial isolates which possess NDM-1 gene were Acinetobacterspecies (58.82\%) followed by E.coli (23.52\%) and Klebsiella species (17.64\%)

NDM -1 gene was most commonly found in patients admitted in ICU for acute exacerbation of COPD. This may be due to multiple episodes of hospital stay and repeated antibiotic administration. 
NDM-1 gene was more commonly seen in isolates obtained from patients who had past history of hospitalization and prior admission to ICU.

\section{Discussion}

In our study, most of the MDR Gram negative isolates were obtained from patients in the age group between 61-70 yrs. Majority if the patients with NDM-1 gene isolates (35.3\%) were also in the same age group. This finding is in concordance with the study by Chakraborthy et al in 2010 at Kolkata. Most of the studies worldwide showed increase in number of MBL producers among the elderly people between 61-80 yrs. This could be due to the association of more comorbidities and more hospital visits, hospital/ICU admissions by elderly people compared to younger age group population.

MDR Gram negatve isolates were most commonly obtained from sputum samples $(42.3 \%)$ in our study. Swaminathan et al 2011-2012 from Kerala noted that urine was the most common source of MBL producers in their study.

A study on high prevalence of blaNDM variants among carbapenem resistant E.coli in Northern Jiangsu Province, China by Kong et al showed New Delhi Metallobetalactamase (NDM) are widely distributed in China. In the study, 54 carbapenemase resistant Escherichia isolates were collected from 5 hospitals. 31 of them were found to carry bla NDM-5 gene (54.7\%).

In the United States, NDM-1 has been reported as a minor cause of carbapenemase resistance. Though, bla NDM has been circulating since 2010, only $230 \mathrm{NDm}$ isolates had beenreported as of June 2017. The rest of the carbapenemase resistance was due to Klebsiella pneumonia carbapenemases (KPCs)

The proportion of NDM-1 gene positive isolates obtained in our study was $8.5 \%$. a similar finding was observed in a study conducted at Kashmir in 2014.

The predominant MDR Gram ngative isolates obtained in the study was Acinetobacter species (31.73\%). In a study at Kolkata in 2010,
Pseudomonas species was the predominant species. A study conducted in Kuwait in 2014 and Haryana in 2018, have reported that Klebsiella pneumonia was the predominant species producing New Delhi Metallobetalactamases (NDM-1) among the Enterobacteriaceae.

\section{Risk Factors Associated with MDR Gram Negative Bacteria}

Out of the 104 MDR Gram negative isolates, 59 isolates $(56.73 \%)$ and $47 \%$ of the isolates with NDM-1 had past history of hospitalization. There was a significant association between previous hospitalization of the patient and multidrug resistant Gram negative bacteria and NDM-1 isolates.

In our study, 36 patients $(34.6 \%)$ had prior ICU admission. 3 out of 17 (17.64\%) patients with NDM-1 isolates had prior ICu admission. In 2017, Zaha et al in Rumania, have proved that 7 day stay in ICU leads to colonization with MDR strain which is an increased risk factor for carbapenemase resistant Gram negative bacterial infection.

MDR Gram negative isolates obtained from $86.5 \%$ of patients and $88 \%$ of isolates with NDM1 gene were treated with antibiotics. The association between antibiotic usage in present admission and multidrug resistant Gram negative bacteria has been proved as statistically significant.

Inappropriate antibiotic use especially for prolonged periods selects out the antibiotic resistant bacteria and disrupts the antibiotic susceptible flora in these patients. This is the prime reason behind the development of drug resistant bacteria.

\section{Co-Morbidities and MDR}

Diabetes patients with MDR Gram negative isolates were 53\% and with NDM-1 isolates were $47 \%$ in our study. No significant association was observed between these two factors. A study in 2012 by Chakraborty et al reported that diabetes 
was the most common predisposing factor for the development of MDR bacteria.

Hypertension was found in $38 \%$ of the patients with MDR Gram negative isolates and $41 \%$ of patients with NDM-1. There was no significant association observed.

Coronary Artery disease was seen in $23 \%$ of patients with MDR Gram negative isolates and $11.76 \%$ of isolates with NDM-1

COPD was found to be a risk factor in patients admitted with acute exacerbation in ICUs from whom MDR isolates were obtained and NDM-1 were detected. In our study $13.46 \%$ of patients with COPD were nfectef by MDR Gram negative bacteria and had NDM-1 gene. This may be due to multiple episodes of admission in ICU and repeated antibiotic administration.

Other co-morbidities observed in our study were cardiovascular accident, anemia, heart failure, bronchiectasis, chronic kidney disease, peripheral occlusive vascular disease etc.

\section{NDM-1 and Aztreonam}

All the 17 isolates with NDM-1 in our study were resistant to Aztreonam. The failure of aztreonam against MBL producers may be due to inactivation of the drug by the presence of multiple betalactamases such as ESBL, AmpC and OXA along with MBL or by a different mechanism of resistance other than enzymatic inactivation.

In vitro study conducted by Pragasam et al in CMC, Vellore in 2019 proved the efficacy of the combination of Ceftazidime/Avibactum with Aztreonam in the treatment against CRE. It was reported that Aztreonam was the most suitable target against MBL producers when coupled with an active betalactamase inhibitor

\section{Outcome}

Majority of the patients with MDR Gram negative isolates (54.8\%) and NDM-1(52.9\%) were improved after antibiotic treatment. In spite of appropriate antibiotic therapy, $41.17 \%$ of the patients who had infection with MDR Gram negative isolates expired. Chakraborty et al in
2010 in Kolkata reported mortality rate of $54.6 \%$. In our study, mortality rate was $41 \%$ which is less than the above mentioned study.

This study points out the importance of appropriate antimicrobial stewardship that includes optimal selection, dose and duration of treatment, control of antibiotic use that will prevent emergence of MDR bacteria.

\section{Conclusion}

The study on multidrug resistant Gram negative bacteria isolated from patients admitted in various ICUs at Govt Medical College Hospital, Ernakulam for a period of One year from $1^{\text {st }}$ July 2018 to $30^{\text {th }}$ June 2019 was conducted in the Dept of Microbiology. A total number of 200 isolates obtained from culture of clinical samples such as sputum, urine, exudates, sterile fluids and blood were included in the study. Out of the 200 isolates, $164(82 \%)$ were Gram negative and $36(18 \%)$ were gram positive bacteria. Among the 164 Gram negative isolates, 104(52\%) were multidrug resistant. The predominant MDR Gram negative isolate was Acinetobacter species (31.73\%) followed by Klebsiella species (29.8\%) and E.coli $(26.92 \%)$. Majority of the isolates are obtained from sputum sample $(42.3 \%)$. Proportion of metallobetalactamase producers in the study was $31.5 \%$. Proportion of isolates with NDM-1 gene was $8.5 \%$. predominant isolates with NDM-1 gene were Acinetobacter species (58.82\%) followed by E.coli (23.5\%) and Klebsiella (17.64\%). MBL producers were detected by phenotypic screening tests such as Double Disk Synergy Test (DDST) and Modified Hodge Test (MHT). Sensitivity of DDST was $88.2 \%$. Specificity of MHT was $97.8 \%$. NDM-1 gene was detected by RT PCR. Association between MDR isolates and previous hospitalization, prior admission to ICU and antibiotic usage were proved to be statistically significant.

Among patients infected with MDR Gram negative bacteria, $54.8 \%$ were improved after treatment with appropriate antibiotic therapy. Mortality rate in our study was $41 \%$ which is 
lower than the rate reported in previous studies in India. This may be due to early detection of MBL producers among multi-drug resistant Gram negative isolates obtained in ICUs and prompt administration of appropriate antibiotic therapy.

\section{Acknowledgement}

I would like to express my sincere gratitude to Dr. G K Sivaraman, Principal Scientist, Microbiology, Fermentation and Biotechnology Division, ICARCentral Institute of Fisheries Technology, Willington Island, Kochi for his valuable support and immense help in doing genotypic analysis of the isolates obtained in the study

\section{Conflicts of Interest}

There are no conflicts of interest to declare.

\section{References}

1. Chakraborty D, Basu S, Das S. A study on infections caused by metallo beta lactamase producing gram negative bacteria in intensive care unit patients. Am J Infect Dis. 2010;6(2):34-9.

2. Shamsuzzaman SM. NDM1 producing new superbug bacteria: a threat to control infection. Bangladesh Journal of Medical Microbiology. 2011 Jan 24;5(1):1-2.

3. Doyle D, Peirano G, Lascols C, Lloyd T, Church DL, Pitout JD. Laboratory detection of Enterobacteriaceae that produce carbapenemases. Journal of clinical microbiology. 2012 Dec 1;50(12):3877-80.

4. Magiorakos AP, Srinivasan A, Carey RT, Carmeli Y, Falagas MT, Giske CT, Harbarth S, Hindler JT, Kahlmeter G, Olsson-Liljequist B, Paterson DT. Multidrug-resistant, extensively drugresistant and pandrug-resistant bacteria: an international expert proposal for interim standard definitions for acquired resistance. Clinical microbiology and infection. 2012 Mar 1;18(3):268-81.
5. Rahman M, Shukla SK, Prasad KN, Ovejero CM, Pati BK, Tripathi A, Singh A, Srivastava AK, Gonzalez-Zorn B. Prevalence and molecular characterisation of New Delhi metallo- $\beta$-lactamases NDM1, NDM-5, NDM-6 and NDM-7 in multidrug-resistant Enterobacteriaceae from India. International journal of antimicrobial agents. $2014 \mathrm{Jul}$ 1;44(1):307.

6. Shenoy KA, Jyothi EK, Ravikumar R. Phenotypic identification \& molecular detection of blaNDM-1 gene in multidrug resistant Gram-negative bacilli in a tertiary care centre. The Indian journal of medical research. 2014 Apr;139(4):625.

7. Ghafur A, Lakshmi V, Kannain P, Murali A, Thirunarayan MA. Emergence of Pan drug resistance amongst gram negative bacteria! The First case series from India. Journal of Microbiology and Infectious Diseases. 2014 Sep 1;4(03):86-91.

8. Karam G, Chastre J, Wilcox MH, Vincent JL. Antibiotic strategies in the era of multidrug resistance. Critical Care. 2016 Dec;20(1):1-9.

9. Jamal WY, Albert MJ, Rotimi VO. High prevalence of New Delhi metallo- $\beta$ lactamase-1 (NDM-1) producers among carbapenem-resistant Enterobacteriaceae in Kuwait. PloS one. 2016 Mar 31;11(3):e0152638.

10. Chatterjee B, Khanduri N, Kakati B, Kotwal A. Universal Presence of blaNDM1 Gene in Carbapenem-Resistant GramNegative Bacilli in an Indian Hospital in 2015. Journal of Clinical and Diagnostic Research: JCDR. 2017 Sep;11(9):DL01.

11. Khan AU, Maryam L, Zarrilli R. Structure, genetics and worldwide spread of New Delhi metallo- $\beta$-lactamase (NDM): a threat to public health. BMC microbiology. 2017 Dec 1;17(1):101.

12. Kalluru S, Eggers S, Barker A, Shirley D, Sethi AK, Sengupta S, Yeptho K, Safdar 
N. Risk factors for infection with multidrug-resistant organisms in Haryana, India. American journal of infection control. 2018 Mar 1;46(3):341-5.

13. Pragasam AK, Veeraraghavan B, Shankar BA, Bakthavatchalam YD, Mathuram A, George B, Chacko B, Korula P, Anandan S. Will ceftazidime/avibactam plus aztreonam be effective for NDM and OXA-48-Like producing organisms: Lessons learnt from In vitro study. Indian journal of medical microbiology. 2019 Jan 1;37(1):34.

14. Mandell, Douglas, and Bennett's Principles and Practice of Infectious Diseases, $8^{\text {th }}$ Edition: John E. Bennett, MD, MACP, Raphael Dolin, MD and Martin J. Blaser, MD
Abbreviations
AMR - Antimicrobial Resistance
ATCC - American Type Culture Collection
CLSI - Clinical Laboratory Standard Institute
DDST - Double Disk Synergy Test
MHT - Modified Hodge Test
ESBL - Extended spectrum Betalactamase
MBL - Metallobetalactamase
NDM - New Delhi Metallobetalactamase
KPC - Klebsiella pneumonia Carbapenemase
MDR - Multi Drug Resistance
MICU - Medical Intensive Care Unit
CICU - Critical Intensive Care Unit
SICU - Surgical Intensive Care Unit 